and to mark his 25 years at the University. Selection of recipients is made by the faculty of the school. Merritt was chosen for the following reasons:

His editorship of the ALA Newsletter on Intellectual Freedom, 1962 to the present.

Service to the profession in organizations devoted to freedom of information. This has included testimony before legislative committees where he frequently was the only defender of freedom to appear to counterbalance the proponents of restrictive legislation.

A large and distinguished body of writing and speaking in behalf of intellectual freedom.

Success in bringing before students the issues involved in book selection as distinct from censorship.

Considerable individual counseling with threatened librarians, both in person and in correspondence.

Service to the cause of freedom of information, in general, through his work in civic, service and other organizations in communities where he has lived and taught.

Merritt went to the University of Oregon from the University of California at Berkeley, where he had taught for over 20 years. He received his doctoral degree in library science from the University of Chicago library school.

\section{CHICAGO LIBRARY TECHNICIAN PROGRAM}

An expanded two-year library technical assistant program will be offered this fall at the Wilson Campus of Chicago City College to ease the nationwide shortage of librarians. Six prominent Chicago librarians have assisted in the development of the program.

William Woods, Associate Professor and Director of the Library Technology Program at the Wilson Campus, 7047 South Stewart Avenue, said that Wilson has been offering an introductory course in library technology since September, 1967. It was the first of its kind in Chicago. He said: "With the help of the six librarians, who have served as an advisory committee since last April, we have been able to expand our course offerings into a full program to train library technical assistants. The committee represents a variety of types of libraries, and has helped to gear our courses to the specific needs of special library technicians."

Members of the committee are:

Sister Mary Chrysartha, Librarian, Felician College Library, 3800 West Peterson Avenue; Dr. Alex Ladenson, Acting Director, Chicago Public Library, 78 East Washington Street;
Dr. Miriam Peterson, Director, Division of Libraries, Chicago Board of Education, 228 North LaSalle Street;

Miss Anne C. Roess, Supervisor, Library Services, Institute of Gas Technology, 3424 South State Street;

Dr. Fritz Veit, Director of Libraries, Wilson Campus and Chicago State College; and Miss Helen Yast, Librarian, American Hospital Association, Asa S. Bacon Memorial Library, 840 North Lake Shore Drive.

Woods also said: "There are over 1,000 libraries in Chicago alone-in business and industrial organizations, hospitals, factories, schools, government offices, churches, and laboratories. Few of these libraries are adequately staffed. To help ease the shortage of librarians, a new para-professional occupation has been created, that of the library technical assistant. Although our program is the only two-year course for library technical assistants offered in Chicago, there is a national organization called the Council on Library Technology (COLT) with 200 members, representing 80 two-year colleges in the United States and Canada, that has been active in defining the educational requirements for the recently-created position."

Currently, the Wilson Campus offers the following courses in library technology: Introduction to Library Procedures, Audio-visual Procedures, Library Public Service, Materials Acquisition Procedures, Preparation Procedures, Library Practicum, and School Library Procedures. Students in the two-year program will take a general core curriculum in communications skills and social science in addition to the specialized courses. Tuition is free for Chicago residents. Classes are offered in the day and evening and on Saturday mornings.

\section{NEW LIBRARY SCHOOLS ACCREDITED}

Three graduate programs of library education have been officially accredited by the American Library Association according to an announcement issued by the Association's Committee on Accreditation. The newly accredited programs are offered by the School of Library and Informational Science, University of Missouri, Columbia (Ralph H. Parker, Dean); the Ecole de Bibliotheconomie, University of Montreal, Montreal, Quebec (Laurent-G. Denis, Director); and the Department of Librarianship, San Jose State College, San Jose, California (Leslie $\mathrm{H}$. Janke, Chairman). This brings the number of library schools offering programs accredited by the American Library Association to 48 , the highest number yet recorded under the Revised Standards of 1951. 